\title{
Time-varying impacts of different management regimes on vegetation cover in agricultural ditches
}

\author{
F. Levavasseur ${ }^{a, *}$, A. Biarnès ${ }^{b}$, J.S. Bailly ${ }^{c, d}$, P. Lagacherie ${ }^{a}$
}

a INRA, UMR LISAH, F-34060 Montpellier, France

${ }^{\mathrm{b}}$ IRD, UMR LISAH, F-34060 Montpellier, France

${ }^{c}$ AgroParisTech, UMR LISAH, F-34060 Montpellier, France

${ }^{d}$ AgroParisTech, UMR TETIS, F-34093 Montpellier, France

\section{Introduction}

In the field of cultivated catchment hydrology, changes in landscape patterns resulting from different agricultural practices have been extensively studied to obtain information that would aim in reducing the negative impacts of agriculture on hydrological processes. Previous hydrological studies have considered the impact of spatial or temporal variability in the cultivated landscape resulting mainly from agricultural practices on plots, hedgerows and/or grass strips; for example, the effects of the spatial structure of hedgerow networks on evapotranspiration fluxes (Viaud et al., 2005) and the effects of agricultural practices on nitrate contamination in a small agricultural catchment (Ferrant et al., 2013) have been examined. To realistically describe differences in landscape patterns, these studies first attempted to quantify the variability in

\footnotetext{
* Corresponding author. Tel.: +33 499612261; fax: +33467632614.

E-mail addresses: f.levavasseur@gmail.com (F. Levavasseur), biarnes@supagro.inra.fr (A. Biarnès), bailly@agroparistech.fr (J.S. Bailly), lagacherie@supagro.inra.fr (P. Lagacherie).
}

the anthropogenic events under study (e.g., hedgerow settlements and agricultural practices).

Despite the recognition that man-made drainage networks can have a strong impact on the hydrology of cultivated catchments (Krause et al., 2007; Stanchi et al., 2012; Dages et al., 2009), no previous studies have examined the impacts of the spatio-temporal variability of man-made drainage networks on the hydrology of these catchments areas. These impacts should be evaluated in terms of the vegetation cover, which can act on multiple hydrological processes such as flow resistance (Nepf, 2012), pesticide retention (Margoum et al., 2003), sedimentation and adsorption of pollutants (Lecce et al., 2006; Nguyen and Sukias, 2002).

Man-made drainage networks consisting primarily of ditches can have opposing effects on cultivated catchments; the magnitude of these effects can be greater than those of the initially anticipated effects. Most ditches must be managed to prevent them from being filled and invaded by vegetation, as the vegetation can affect their subsequent ability to remove excess water or can result in overflows. Farmers and local authorities can apply a variety of management operations, including dredging or mowing, that are organised within management regimes, as for crop management 


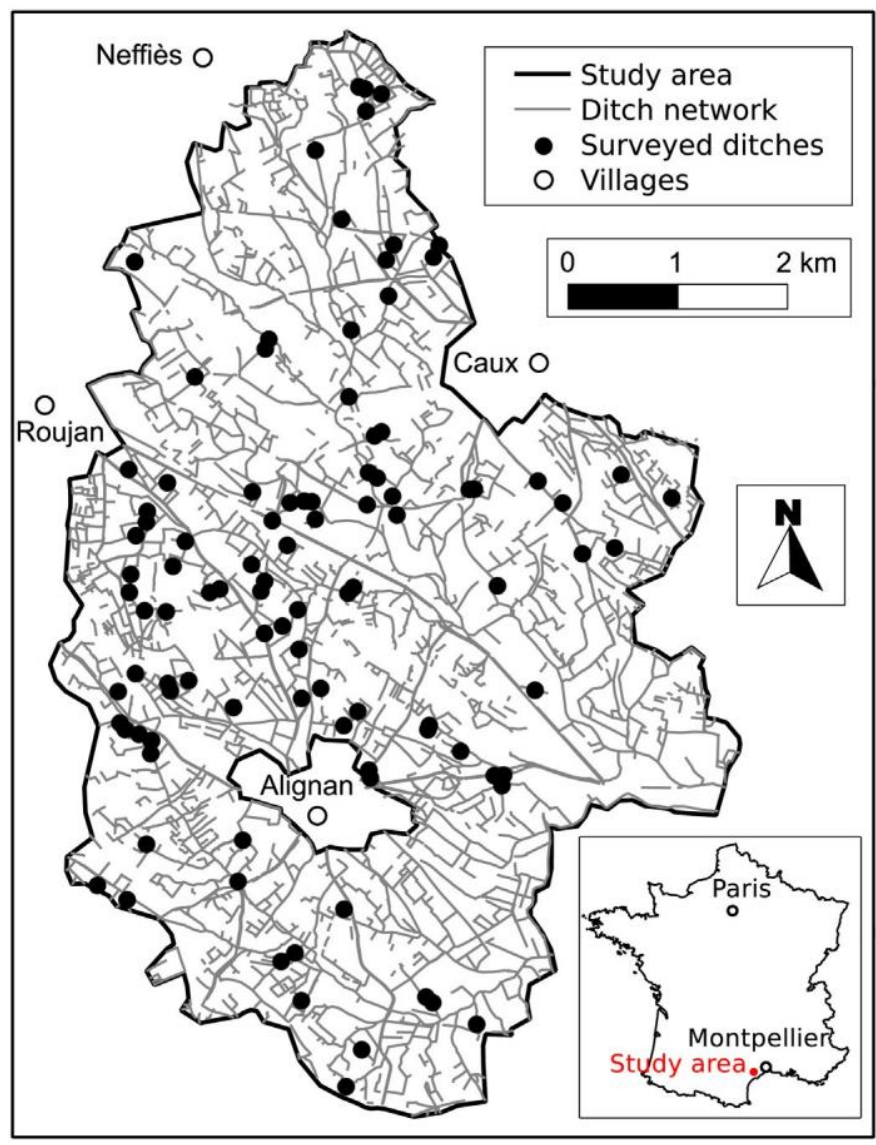

Fig. 1. Study area and ditch networks.

(Paré, 2011). These management regimes, which act on vegetation cover in the ditches, most likely impact the aforementioned hydrological processes.

Few studies in the literature have characterised ditch management regimes or evaluated their impacts on ditch vegetation. Several studies have considered the impact of ditch dredging on the hydrological processes occurring in peatland forest catchments (Koivusaloet al., 2008) and on the nutrient uptake capacity of ditches (Smith and Pappas, 2007); other studies have examined the impact of ditch mowing on temporal patterns of erosion and sedimentation in ditch networks (Lecce et al., 2006). These studies addressed a single aspect of ditch management at a single time point; however, management regimes may impact vegetation cover in multiple ways and may have time-varying effects on hydrological processes. To date, no studies have examined the variety of ditch management regimes currently in use or their consequences for vegetation cover. Such information is needed to subsequently quantify the impacts of ditch management operations on the hydrology of catchments.

The objective of this study was to identify ditch management regimes and to characterise the multiple, time-varying impacts of these regimes on the vegetation cover of ditches. This characterisation will provide a foundation that can be used to discuss the hydrological impacts of these regimes and the resulting vegetation cover. The study uses information obtained from observations made in a Mediterranean vineyard landscape in the south of France.

\section{Study area}

The study area is located in the downstream portion of the Peyne catchment in southern France (Fig. 1). The area is approximately
$40 \mathrm{~km}^{2}$ in extent, and approximately $60 \%$ of the area is covered with vineyards. The altitude ranges from $28 \mathrm{~m}$ to $128 \mathrm{~m}$. The region has a Mediterranean climate, receives $600-800 \mathrm{~mm}$ of precipitation per year and is characterised by two short but intense rainy seasons in the autumn and spring. The vines are currently not irrigated.

The study area is prone to intense periods of Mediterranean rainfall and flooding, during which the ditch networks discharge excess water (Moussa et al., 2002). Soil erosion, which averages a rate of $10.5 \mathrm{t} / \mathrm{ha} / \mathrm{y}$, can be severe and highly spatially variable (Paroissien et al., 2010). The pesticides used in the study area are primarily associated with vineyard husbandry and include herbicides, fungicides and insecticides. Herbicides are applied primarily from March to April, whereas various fungicides and insecticides are applied from April to August (Paré, 2011).

The man-made drainage networks of the study area were completely mapped in a previous study (Levavasseur et al., 2014) (Fig. 1). These networks consist primarily of agricultural and roadside ditches and include sunken paths and channelized rivers. To simplify terminology, we refer to these networks as ditch networks, although they do not consist only of ditches. The principal function of these ditches is to intercept surface runoff during periods of heavy rain and to convey it towards downstream rivers (Levavasseur, 2012). The maintenance of the hydraulic capacity of the ditches during such periods of rainfall is therefore very important. In flat areas, these ditches can also play a role in controlling the level of the water table. The width and depth of the ditches are highly variable, both ranging from $30 \mathrm{~cm}$ to several metres. The mean drainage density is $95 \mathrm{~m}$ of ditches/ha. The vegetation in the ditches consists primarily of herbaceous plants (e.g., Elytrigia juncea, Equisetum arvense, Bromus spp.) and shrubs (e.g., Arundo donax, Rubus fruticosus).

\section{Methods}

To characterise the time-varying effects of the ditch management regimes in the study area on vegetation cover, we surveyed a sample of vine growers and characterised their ditch management regimes. We also visually assessed ditch vegetation to characterise the temporal evolution of the vegetation cover resulting from the management regimes.

\subsection{Characterisation of ditch management regimes}

The management regimes currently in use, the frequency and period of each specific operation for a given ditch and the reasons for the technical choices made by the vine growers were obtained by survey. To maximise the number of vine growers and ditches surveyed in the limited time period of the study and thereby increase the generalisability of our results, we approached farmers in their fields instead of attempting to schedule appointments. A total of 61 vine growers, representing 101 ditches (Fig. 1), were surveyed in May 2011.

\subsection{Ditch vegetation monitoring}

The type and quantity of dead and living vegetation in the bottom of the ditch (the deepest $5 \mathrm{~cm}$ of the ditch perimeter) and living vegetation on the banks of the ditches were recorded six times (in May, August and November of 2011 and in January, March and May 2012). The density of the vegetative material was visually estimated (Fig. 2). Because the living vegetation cover corresponded to the combined grass cover and shrub cover, the estimated cover could surpass $100 \%$. Because the ditches were highly spatially variable and because it was difficult to assess the vegetation cover by visual 


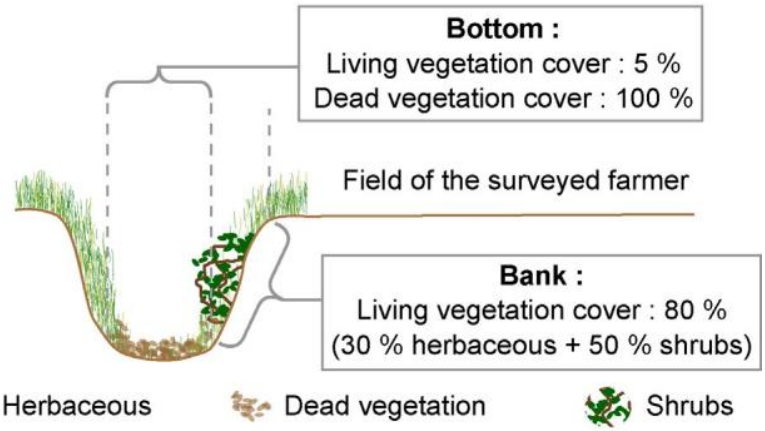

Fig. 2. Example of the vegetation cover in a ditch. The dead and living vegetation cover at the bottom of the ditch and along the ditch banks was visually estimated at different times of the year.

inspection alone, the precision of the estimates was predicted to be approximately $20 \%$. If evidence of a previous different management operation was observed at a survey site, the operation was noted and compared with the survey responses provided by the grower in May 2011.

\section{Results}

\subsection{Characterisation of ditch management regimes}

The results of the survey showed that most of the ditches were actively managed. Four types of ditch management operations were identified: $58 \%, 49 \%, 54 \%$ and $28 \%$ of the ditches were dredged, mowed, burned and chemically weeded, respectively. The frequency of implementation of each type of ditch management operation was highly variable: dredging was undertaken at a median frequency of 0.1 times per year (or once per ten years), whereas the other operations were performed once every year. Dredging and mowing primarily occurred in the summer, chemical weeding occurred in the spring to coincide with the chemical weeding of the vine plots, and burning occurred from mid-October to mid-March when local authorities authorised burning in the area.

Any given ditch could be exposed to a combination of management operations during a single year. We therefore defined

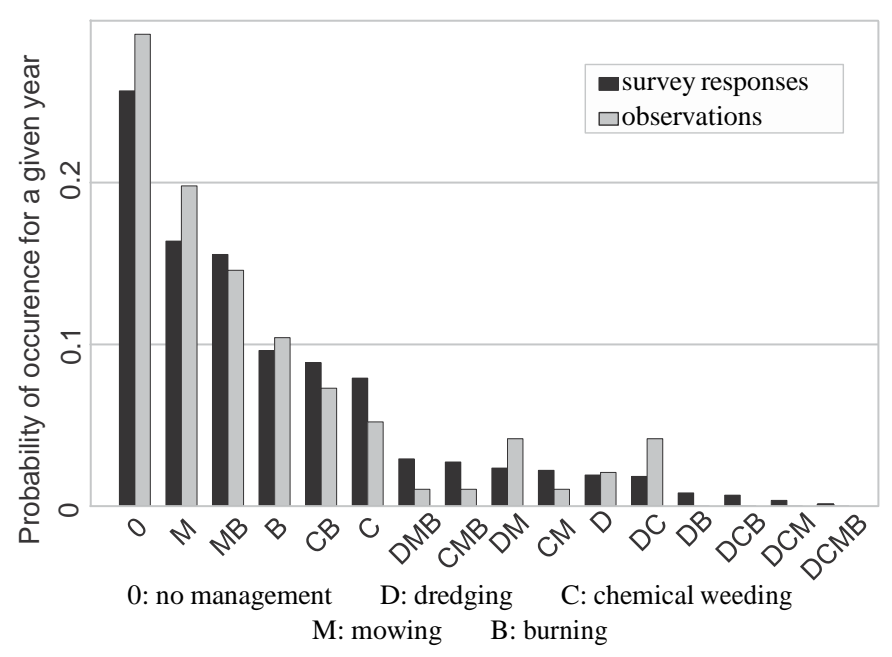

Fig. 3. Probability of occurrence of each management regime for a given year and the percentage of corresponding observations from May 2011 to May 2012. several management regimes characterised by different combinations of ditch management operations conducted over the course of the year. Using the frequency with which an operation was conducted and the order in which the different operations were mentioned in the surveys, we computed the probability of occurrence of each management regime for a given year (Fig. 3). Only six management regimes (no management, mowing only, mowing and burning, burning only, chemical weeding and burning, and chemical weeding only) had a probability of occurrence of more than $5 \%$. The probability of occurrence of these six most prevalent management regimes was 0.84 according to the survey and 0.86 according to the empirical observations; the ranking of these regimes was identical for the surveys and observations, thus validating the results of the survey. In subsequent analyses, only these six management regimes were considered.

\subsection{Impact of management regimes on ditch vegetation}

Fig. 4 illustrates the impact of each management operation on the ditch vegetation covers. An analysis of the annual pattern of the distribution of vegetation along and in the ditches allowed us to quantify the effects of each management regime during the study period (Fig. 5). Sunken roads and rivers were excluded from the analysis (nine ditches).

An increase in the dead vegetation cover at the bottom of the ditches was observed beginning in November 2011 regardless of the applied management regime. This increase coincided with the natural accumulation of dead vegetation (especially dead leaves) in autumn and winter. The increase was greater and occurred earlier in the mowed ditches (MR 4 and 5), as mowed vegetation from the banks of the ditch tended to accumulate at the bottom of these ditches. Chemical weeding also increased the accumulation of dead vegetation at the bottom of the ditches (MR 2 and 3). In contrast, burning at the end of winter removed almost all of the dead vegetation from the bottom of the ditches (MR 3, 5 and 6). A less pronounced decrease in the dead vegetation cover at the bottom of the ditches was also observed for non-burned ditches in May 2012. We assumed that this decrease was related to the flows of water following spring rainfall events.

Regardless of the applied management regime, the living vegetation cover on the bottom of the ditches remained low throughout the year (almost always lower than 50\%). In March of 2012, burning markedly impacted the living vegetation cover (MR 3, 5 and 6). Chemically weeded ditches also appeared to have less living vegetation at the bottom of the ditch; however, the differences among the other ditches were low.

The management regime had a clearly detectable impact on the living vegetation cover on the banks of the ditch. Chemically weeded ditches had less living vegetation on their banks throughout the year than the other ditches. The living vegetation almost completely disappeared from burned ditches (MR 3, 5 and 6) from January 2012 to March 2012 (i.e., when most of the burning occurred). Mowed ditches (MR 4 and 5) also had less living vegetation cover in August and November 2011 (i.e., when most of the mowing took place). However, this decrease was less pronounced than the decrease observed in burned ditches, as taller plants were partly replaced with shorter plants in the mowed ditches. We observed a progressive decrease in the amount of living vegetation on the banks of unmanaged ditches from November 2011 to March 2012; we assumed that this decrease was related to the natural senescence of vegetation in autumn and winter. Finally, the regrowth of vegetation on the banks of almost all of the ditches was limited from March 2012 to May 2012. 


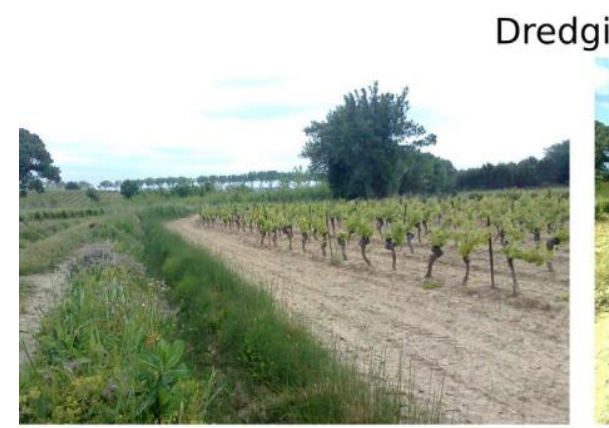

Beginning in May 2011

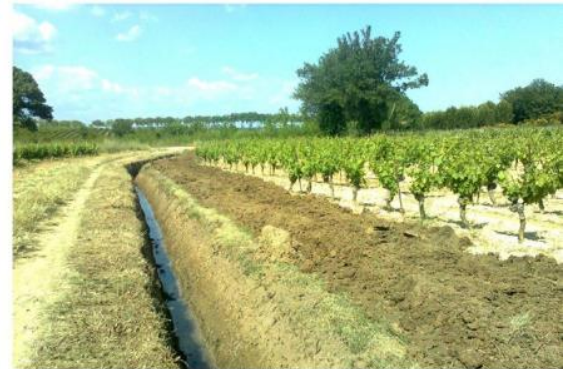

Mid-May 2011

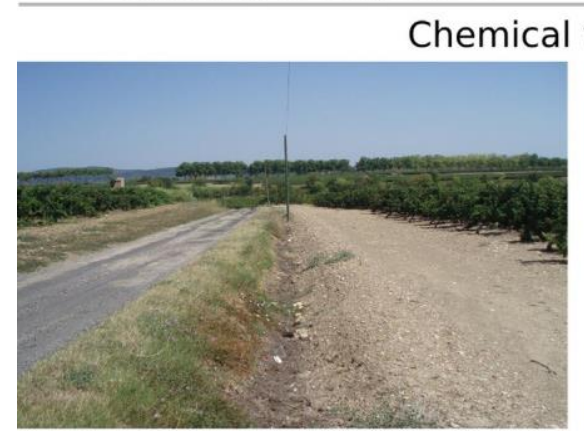

August 2011

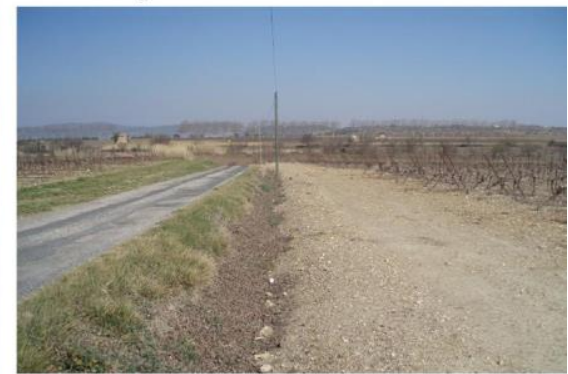

January 2012

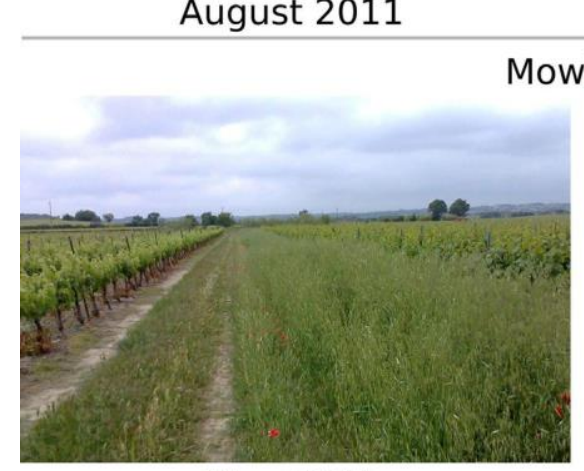

May 2011

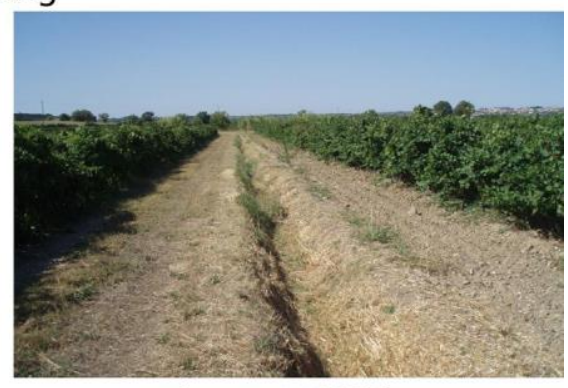

August 2011

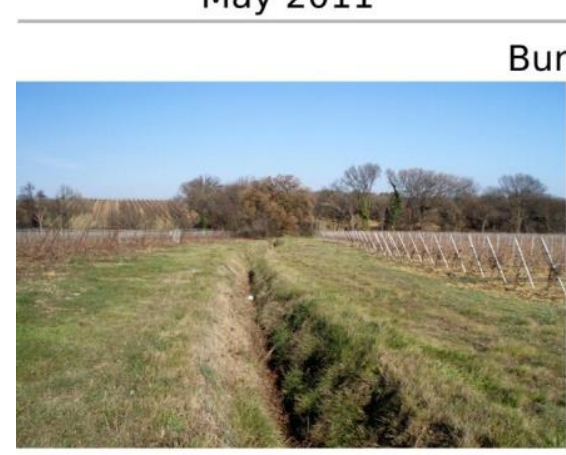

November 2011

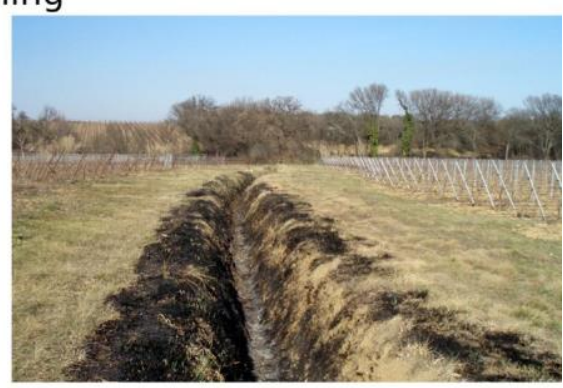

January 2012

Fig. 4. Illustration of the effects of each type of management operation.

\section{Discussion}

5.1. Spatial and temporal variability in vegetation cover resulting from ditch management regimes

We found that the yearly management operations had a strong impact on the vegetation cover in the ditches (e.g, burning removed almost all of the living and dead vegetation). The senescence of living vegetation, the accumulation of dead vegetation and regrowth also impacted the vegetation cover.
The various yearly management operations were not mutually exclusive and occurred at different periods throughout the year. Different ditch management regimes (Fig. 3) that were characterised by a temporal pattern of ditch vegetation cover (Fig. 5) could therefore be defined. In addition, two main types of variability in vegetation cover were defined:

- temporal variability in the vegetation cover that varied with the pattern of ditch management operations, 

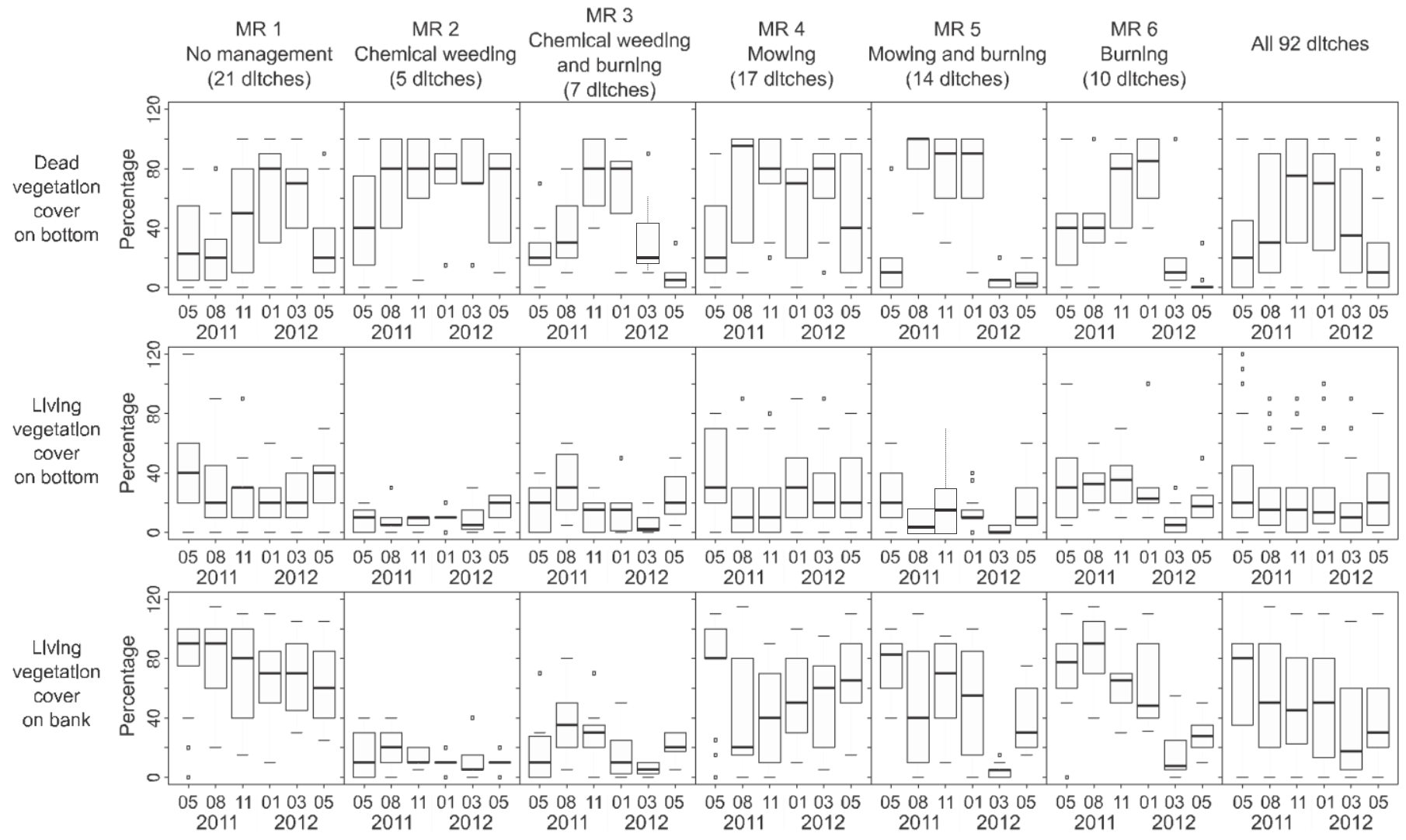

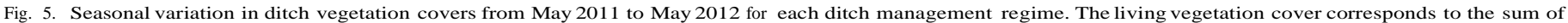

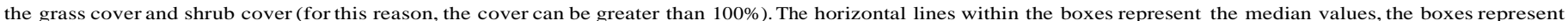

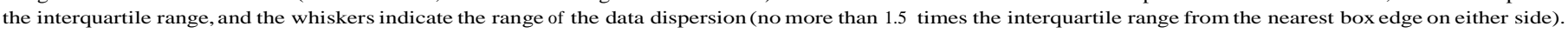

- spatial variability in the vegetation cover at a given time that varied with the type of management regimes that was applied.

For example, certain ditches could be entirely covered by vegetation at a given time of the year but could have almost completely bare soil at another time (e.g., certain mowed and burned ditches), whereas other ditches had bare soil throughout the year (e.g., certain chemically weeded ditches). The management regimes observed in our study and the resulting patterns of ditch vegetation cover were therefore much more complex than those presented in the literature (Milsom et al., 2004; Blomqvist et al., 2006; Lecce et al., 2006; Manhoudt and Visser, 2007; Smith and Pappas, 2007; Koivusalo et al., 2008).

\subsection{Potential hydrological impacts of ditch management regimes}

\subsubsection{Hydraulic capacity and ditch bank erosion}

The living vegetation cover was more dense during the main rainy season (October-November 2012), than during the other periods of the year (Fig. 5), in all ditches except the chemically weeded ditches. We can therefore hypothesise that the hydraulic capacity of the ditches was not maximal at that time. The presence of living vegetation cover during this rainy season could limit the erosion of ditch banks and favour sedimentation in ditches (Stott, 2005; Lecce et al., 2006). Conversely, chemically weeded ditches (MR 2 and 3) appeared to be sensitive to ditch bank erosion during the intense rain events of autumn.

The hydraulic capacity of most of the ditches was expected to be maximal during the spring rainy season (March-May 2012), as burning conducted at the end of the winter and chemical weeding conducted in spring minimised the living vegetation cover in the ditches (Fig. 5). This lack of living vegetation in the spring rainy season could promote the erosion of the banks of the ditches. Ultimately, farmers must adopt management practices that favour the flow of water in the ditch to prevent its overflow and the formation of gullies while limiting the erosion of the banks and sedimentation to avoid the cost associated with ditch dredging (Martnez-Casasnovas and Ramos, 2006). Because each management regime was associated with contrasting and time-varying effects, achieving both of these objectives is most likely difficult during the autumn and spring rainy seasons.

\subsubsection{Pesticide transfer}

To limit the transfer of pesticides into ditches during rainfall events of low-to-moderate intensity, the retention of pesticides at the bottom of the ditches can be promoted; more specifically, the vegetation (particularly the dead vegetation), can act as a sorption site for pesticides (Margoum et al., 2003; Bennett et al., 2005; Moore et al., 2008; Rogers and Stringfellow, 2009). The presence of such retention sites would be of particular benefit when the pesticide are sprayed (spring and early summer). However, as shown in Fig. 3, the dead vegetation cover was low in March and May 2012 in all ditches except those managed with chemical weeding and mowing (MR 2 and MR 4). The effect of burning on the dead vegetation cover was particularly pronounced (MR 3, 5 and 6). These results suggest that vegetation control measures aimed at favouring the hydraulic capacities of the ditch during the spring may negatively impact the ability of these ditches to retain pesticides. The direct spraying of pesticides within the ditches may also increase water contamination. 


\section{Conclusion}

We found that most of the observed ditches were managed at least once a year, which was surprisingly frequent for nonproductive terrains. The observed management regimes were characterised by a combination of dredging, chemical weeding, mowing and burning. These management regimes have a drastic impact on ditch vegetation: strong spatial and temporal variability in the vegetation cover among ditches and within a given ditch, respectively, was observed. It is probable that the actual management regimes applied to the ditches had time-varying and contrasting impacts on the hydraulic capacity of ditches, the erosion of ditch banks and sedimentation and pesticide retention in the ditches, as indicated by the extensive literature on these topics.

In the future, the variability of ditch vegetation should be characterised in greater depth to consider impacts of ditch management regimes, climate and soils on vegetation cover in and along the ditches. Models of vegetation growth in ditches could also be developed to help to understand spatial and temporal variability in ditch vegetation cover at the catchment scale. Finally, field experiments investigating the impacts of ditch management regimes on flow resistance, ditch bank erosion or pesticide retention could be conducted.

\section{Acknowledgements}

This work was partly supported by funds for a $\mathrm{PhD}$ thesis provided by the region of Languedoc-Roussillon. The authors thank the farmers and the local authorities for their hospitality during the survey period of this study. The authors also thank the longterm environmental research observatory (OMERE) for providing the meteorological data.

\section{References}

Bennett, E.R., Moore, M.T., Cooper, C.M., Smith Jr., S., Shields Jr., F.D., Drouillard, K.G., Schulz, R., 2005. Vegetated agricultural drainage ditches for the mitigation of pyrethroid-associated runoff. Environ. Toxicol. Chem. 24 (9), 2121-2127, http://dx.doi.org/10.1897/04-357R.1.

Blomqvist, M., Tamis, W., Bakker, J., van der Meijden, E., 2006. Seed and (micro)site limitation in ditch banks: germination, establishment and survival under different management regimes. J. Nat. Conserv. 14 (1), 16-33, http://dx.doi.org/10.1016/j.jnc.2005.08.003.

Dages, C., Voltz, M., Bsaibes, A., Prvot, L., Huttel, O., Louchart, X., Garnier, F., Negro, S., 2009. Estimating the role of a ditch network in groundwater recharge in a Mediterranean catchment using a water balance approach. J. Hydrol. 375 (3-4), 498-512, http://dx.doi.org/10.1016/j.jhydrol.2009.07.002.

Ferrant, S., Durand, P., Justes, E., Probst, J.-L., Sanchez-Perez, J.-M., 2013. Simulating the long term impact of nitrate mitigation scenarios in a pilot study basin. Agric. Water Manage. 124 (0), 85-96, http://dx.doi.org/10.1016/j.agwat.2013.03.023.

Koivusalo, H., Ahti, E., Laurn, A., Kokkonen, T., Karvonen, T., Nevalainen, R., Finr, L., 2008. Impacts of ditch cleaning on hydrological processes in a drained peatland forest. Hydrol. Earth Syst. Sci. 12, 1211-1227.
Krause, S., Jacobs, J., Bronstert, A., 2007. Modelling the impacts of land-use and drainage density on the water balance of a lowland-floodplain landscape in northeast Germany. Ecol. Model. 200 (3-4), 475-492, http://dx.doi.org/10.1016/ j.ecolmodel.2006.08.015.

Lecce, S.A., Pease, P.P., Gares, P.A., Wang, J., 2006. Seasonal controls on sediment delivery in a small coastal plain watershed, North Carolina, USA. Geomorphology 73 (3-4), 246-260, http://dx.doi.org/10.1016/j.geomorph.2005.05.017.

Levavasseur, F., Lagacherie, P., Bailly, J.S., Biarnès, A., Colin, F., 2014. Spatial modeling of man-made drainage density of agricultural landscapes. J. Land Use Sci, in press.

F. Levavasseur, Structure du paysage et fonctionnement hydrologique: application aux rseaux de fosss en zone viticole mditerranenne, Montpellier SupAgro, Montpellier, France, 2012 (Ph.D. thesis).

Manhoudt, A., Visser, A., de Snoo, G., 2007. Management regimes and farming practices enhancing plant species richness on ditch banks. Agric. Ecosyst. Environ. 119 (3-4), 353-358, http://dx.doi.org/10.1016/j.agee.2006.08.004.

Margoum, C., Gouy, V., Laillet, B., Dramais, G., 2003. Rétention des produits phytosanitaires dans les fossés de connexion parcelle-cours d'eau. J. Water Sci. 16 (4), 389-405.

Martnez-Casasnovas, J., Ramos, M., 2006. The cost of soil erosion in vineyard fields in the Penedès-Anoia region (NE Spain). CATENA 68 (2-3), 194-199, http://dx.doi.org/10.1016/j.catena.2006.04.007.

Milsom, T., Sherwood, A., Rose, S., Town, S., Runham, S., 2004. Dynamics and management of plant communities in ditches bordering arable fenland in eastern England. Agric. Ecosyst. Environ. 103 (1), 85-99, http://dx.doi.org/ 10.1016/j.agee.2003.10.012

Moore, M.T., Denton, D.L., Cooper, C.M., Wrysinski, J., Miller, J.L., Reece, K., Crane, D., Robins, P., 2008. Mitigation assessment of vegetated drainage ditches for collecting irrigation runoff in California. J. Environ. Quality 37 (2), 486-493, http://dx.doi.org/10.2134/jeq2007.

Moussa, R., Voltz, M., Andrieux, P., 2002. Effects of the spatial organization of agricultural management on the hydrological behaviour of a farmed catchment during flood events. Hydrol. Process. 16 (2), 393-412, http://dx.doi.org/ 10.1002/hyp.333.

Nepf, H., 2012. Hydrodynamics of vegetated channels. J. Hydraulic Res. 50 (3), 262-279.

Nguyen, L., Sukias, J., 2002. Phosphorus fractions and retention in drainage ditch sediments receiving surface runoff and subsurface drainage from agricultural catchments in the North Island, New Zealand. Agric. Ecosyst. Environ. 92 (1), 49-69, http://dx.doi.org/10.1016/S0167-8809(01)00284-5.

N. Paré, Pollution de l'eau par les pesticides en milieu viticole languedocien. construction d'un modèle couplé pression-impact pour l'expérimentation virtuelle de pratiques culturales à l'échelle de petits bassins versants, Montpellier SupAgro, Montpellier, France, 2011 (Ph.D. thesis).

Paroissien, J., Lagacherie, P., Le Bissonnais, Y., 2010. A regional-scale study of multi-decennial erosion of vineyard fields using vine-stock unearthingburying measurements. CATENA 82 (3), 159-168, http://dx.doi.org/ 10.1016/j.catena.2010.06.002.

Rogers, M.R., Stringfellow, W.T., 2009. Partitioning of chlorpyrifos to soil and plants in vegetated agricultural drainage ditches. Chemosphere 75 (1), 109-114, http://dx.doi.org/10.1016/j.chemosphere.2008.11.036.

Smith, D.R., Pappas, E.A., 2007. Effect of ditch dredging on the fate of nutrients in deep drainage ditches of the midwestern United States. J. Soil Water Conserv. 62 (4), 252-261.

Stanchi, S., Freppaz, M., Agnelli, A., Reinsch, T., Zanini, E., 2012. Properties, best management practices and conservation of terraced soils in southern Europe (from Mediterranean areas to the Alps): a review. Quaternary Int. 265, 90-100, http://dx.doi.org/10.1016/j.quaint.2011.09.015.

Stott, T., 2005. Natural recovery from accelerated forest ditch and stream bank erosion five years after harvesting of plantation forest on plynlimon, midwales. Earth Surf. Process. Landforms 30 (3), 349-357, http://dx.doi.org/ 10.1002/esp. 1163

Viaud, V., Durand, P., Merot, P., Sauboua, E., Saadi, Z., 2005. Modeling the impact of the spatial structure of a hedge network on the hydrology of a small catchment in a temperate climate. Agric. Water Manage. 74 (2), 135-163, http://dx.doi.org/ 10.1016/j.agwat.2004.11.010. 